\title{
KARAKTERISTIK SIFAT FISIKOKIMIA PATI UBI JALAR DENGAN MENGKAJI JENIS VARIETAS DAN SUHU PENGERINGAN
}

\section{Physicochemical Properties of Sweet Potato Starches by Studying Their Varie- ties and Drying Temperatures}

\author{
Irhami $^{1 *}$, Chairil Anwar2, Mulla Kemalawaty ${ }^{2}$ \\ ${ }^{1}$ Program Studi Agroindustri, Politeknik Indonesia Venezuela, Aceh Besar \\ J1. Bandara Iskandar Muda Km 12 Desa Cot Suruy, Kecamatan Ingin Jaya Kabupaten Aceh Besar 23372 \\ ${ }^{2}$ Program Studi Pengolahan Hasil Ternak, Politeknik Indonesia Venezuela, Aceh Besar \\ J1. Bandara Iskandar Muda Km 12 Desa Cot Suruy, Kecamatan Ingin Jaya Kabupaten Aceh Besar 23372 \\ *Penulis Korespondensi: email: irhamistp@yahoo.co.id
}

Disubmit: 24 Agustus 2018 Direvisi: 9 Januari 2019 Diterima: 26 Maret 2019:

\begin{abstract}
ABSTRAK
Ubi jalar merupakan sumber karbohidrat yang memiliki potensi untuk dikembangkan sebagai bahan pengganti beras. Ubi jalar mempunyai keragaman jenis yang terdiri atas jenis lokal dan beberapa varietas unggul. Ubi jalar dapat dimanfaatkan sebagai bahan pangan, pakan ternak, dan bahan baku industri. Pati merupakan salah satu bentuk pengolahan ubi jalar yang dapat dimanfaatkan sebagai bahan baku di industri, baik pangan maupun nonpangan. Penelitian ini bertujuan mengetahui varietas ubi jalar dan suhu pengeringan terbaik terhadap sifat fisik dan kimia pati ubi jalar. Penelitian menggunakan Rancangan Acak Lengkap (RAL) faktorial yang terdiri atas dua faktor yaitu faktor varietas ubi jalar (A) dan suhu pengeringan (B). Faktor varietas ubi jalar $(\mathrm{A})$ terdiri atas empat taraf, yaitu $\mathrm{A} 1$ = varietas lokal, $\mathrm{A} 2$ = varietas muara, $\mathrm{A} 3=$ varietas jago, dan $\mathrm{A} 4=$ varietas sukuh. Faktor suhu pengeringan (B) terdiri atas tiga taraf yaitu $\mathrm{B} 1=40^{\circ} \mathrm{C}, \mathrm{B} 2=50^{\circ} \mathrm{C}$, dan $\mathrm{B} 3=60^{\circ} \mathrm{C}$. Hasil penelitian menunjukkan bahwa faktor varietas ubi jalar berpengaruh sangat nyata terhadap rendemen, suhu gelatinisasi, swelling power, kadar air, dan berpengaruh nyata terhadap organoleptik warna pati ubi jalar yang dihasilkan. Faktor suhu pengeringan berpengaruh sangat nyata terhadap swelling power dan kadar air pati ubi jalar. Faktor interaksi antara varietas ubi jalar dan suhu pengeringan berpengaruh tidak nyata terhadap kadar abu pati ubi jalar. Berdasarkan analisis organoleptik pati ubi jalar yang disukai oleh panelis adalah pati ubi jalar dari varietas muara dengan suhu pengeringan $60^{\circ} \mathrm{C}$ dengan nilai kesukaan warna 3.69 (penerimaan antara biasa sampai suka).
\end{abstract}

Kata kunci: Fisikokimia Pati Ubi Jalar; Suhu Pengeringan; Varietas Ubi Jalar

\begin{abstract}
Sweet potatoes are source of carbohydrates that have potential to be developed as a substitute for rice. Sweet potato has a variety of species consisting of local species and several superior varieties. Sweet potatoes can be used as food, animal feed, and industrial raw materials. Starch is one form of sweet potato processing that can be used as raw material among industries, both food, and non-food industries. This study aims to determine the sweet potato variety and the best drying temperature for the physical and chemical properties of sweet potato starch. This study uses factorial completely randomized design (CRD) consisting of two factors, sweet potato variety (A) and drying temperature (B). Sweet potato varieties consisted of four levels $A 1=$ local varieties, $A 2=$ muara varieties, $A 3=$ jago varieties, and $A 4=$ sukuh varieties. Drying temperature factor $(B)$ consists of three levels, $B 1=40^{\circ} \mathrm{C}, B 2=50^{\circ} \mathrm{C}$, and $B 3=60^{\circ} \mathrm{C}$. The results showed that sweet potato varieties had a very significant effect on yield, gelatinization temperature, swelling power, water content, and significantly affected to the organoleptic color of sweet potato starch produced. Drying temperature factor had a very significant effect on swelling power and moisture content of sweet potato starch. The interaction factors between sweet potato varieties and drying temperature had no significant
\end{abstract}


effect on the levels of sweet potato starch ash. Based on the analysis of organoleptic sweet potato starch preferred by the panelists are sweet potato starch from muara varieties with a drying temperature of $60^{\circ} \mathrm{C}$ with a favorite value of color 3.69 (acceptance between normal to like)

Keyword: Drying Temperature; Physicochemical Sweet Potato Starch; Sweet Potato Varieties

\section{PENDAHULUAN}

Ubi jalar merupakan sumber karbohidrat yang dapat dimanfaatkan sebagai sumber bahan pangan, pakan ternak, dan bahan baku industri. Ubi jalar adalah tanaman merambat yang sangat banyak ragamnya. Ubi jalar dalam bentuk segar mudah rusak akibat faktor mekanik, fisiologis, dan mikrobiologis yang berkaitan dengan kadar air yang tinggi serta tidak tahan lama disimpan. Ubi jalar yang mudah rusak ini dapat diolah menjadi berbagai macam produk olahan. Salah satu bentuk pengolahan ubi jalar yaitu pengolahan menjadi pati.

Pati didapatkan melalui proses ekstraksi karbohidrat yakni pengecilan ukuran melalui grinding (pemarutan) dilanjutkan proses ekstraksi dengan memakai pelarut (biasanya air) untuk mengeluarkan kandungan pati melalui sendimentasi atau pengendapan, selanjutnya dikeringkan pada suhu dan lama waktu tertentu hingga mendapatkan pati yang siap digunakan (Martunis, 2012).

Pati ubi jalar diperoleh dari umbi ubi jalar dengan sistem pengolahan basah. Proses pembuatan pati ubi jalar di Indonesia masih belum berkembang, seperti halnya pati dari ubi kayu atau tapioka yang berkembang pesat. Pemilihan varietas ubi jalar sangatlah penting dan harus disesuaikan dengan tujuan pemanfaatannya, karena setiap jenis ubi jalar memiliki karakteristik tertentu. Menurut Jusuf et al., (1998), pemilihan jenis ubi jalar yang digunakan untuk suatu jenis produk tertentu memiliki kriteria-kriteria yang harus diperhatikan, misalnya untuk pembuatan tepung ubi jalar hendaknya menggunakan varietas yang memiliki rendemen tepung yang lebih dari $25 \%$ dengan bentuk umbi yang bagus.

Pengawetan ubi jalar sebelum dilakukan proses pengolahan menjadi pati adalah dengan pengeringan. Secara umum, pengeringan pati dapat dilakukan dengan dua cara yaitu pengeringan dengan sinar matahari dan alat pengering. Pengeringan pati dengan cara penjemuran masih dilakukan oleh industri tapioka. Keuntungan dari pengeringan dengan menggunakan sinar matahari yaitu lebih murah dan mudah. Pengeringan ini juga memiliki kelemahan, yaitu berjalan sangat lambat sehingga memungkinkan terjadinya pembusukan sebelum bahannya cukup kering. Kelemahan lainnya yaitu, hasil pengeringan tidak merata serta adanya kontaminan dari debu selama proses pengeringan. Transfer panas yang tidak merata kedalam bahan juga akan menyebabkan pati menjadi lembab, berbau asam, dan menyebabkan timbulnya jamur sehingga dapat menurunkan mutu pati.

Selain menggunakan pengering dengan matahari, maka salah satu alternatif lainnya adalah dengan menggunakan pengeringan buatan (oven). Proses pengeringan menggunakan oven memiliki keuntungan yakni suhu dan waktu pemanasan yang dapat diatur (Alim, 2004). Berkaitan dengan proses pengeringan. Novary (1997) mengungkapkan bahwa waktu dan suhu pengeringan yang digunakan tidak dapat ditentukan dengan pasti untuk setiap bahan pangan, namun hal tersebut bergantung pada jenis bahan yang dikeringkan, diantaranya untuk jenis bubuk bahan pangan menggunakan suhu $40-60{ }^{\circ} \mathrm{C}$ selama 6-8 jam. Pada proses pengeringan pati dengan bantuan alat pengering maka proses tersebut dapat berlangsung lebih cepat yaitu sekitar 6 jam (Suismono, 2002). Untuk menghasilkan pati ubi jalar yang baik maka diperlukan penelitian untuk menentukan suhu terbaik dari beberapa varietas ubi jalar. Penelitian ini bertujuan untuk mengetahui karakteristik sifat fisikokimia pati ubi jalar dengan mengkaji jenis varietas dan suhu pengeringan.

\section{METODE}

Bahan yang digunakan pada penelitian ini adalah ubi jalar dari empat varietas 
yaitu varietas lokal yang berwarna daging umbi kuning, varietas muara yang berwarna daging umbi jingga, varietas jago dan varietas sukuh yang berwarna daging umbi putih dengan umur panen 4-4.5 bulan. Bahan-bahan tersebut diperoleh dari kebun percobaan program studi Pengelolaan Perkebunan Politeknik Indonesia Venezuela Bahan-bahan lainnya adalah aquades, eter, $\mathrm{NaOH} 1 \%$, dan $\mathrm{H}_{2} \mathrm{SO}_{4} 25 \%$ yang diperoleh dari laboratorium Analisis Hasil Pertanian Universitas Syiah Kuala.

Alat yang digunakan pada penelitian ini adalah beaker glass, erlenmeyer dan gelas piala merk Pyrex, oven merk J Labtech, sentrifuge merk Gyrozen Type 2236HR, neraca analitik merek Matler Toledo type AL204, ayakan, hammer mill JFS-2000, waterbath DSB500E merk Daihan Labtech, desikator DN 300 merk Duran.

Penelitian ini menggunakan Rancangan Acak Lengkap (RAL) dengan pola faktorial 3x3 yang terdiri atas dua faktor yaitu faktor varietas ubi jalar (A) dan suhu pengeringan (B). Faktor varietas ubi jalar (A) terdiri atas empat taraf, yaitu A1 = varietas lokal, A2 = varietas muara, $\mathrm{A} 3$ = varietas jago, dan A4 $=$ varietas sukuh. Faktor suhu pengeringan (B) terdiri atas tiga taraf yaitu B1 $=40^{\circ} \mathrm{C}$, B2 $=50^{\circ} \mathrm{C}$, dan $\mathrm{B} 3=60^{\circ} \mathrm{C}$. Setiap perlakuan dilakukan 3 kali ulangan.

\section{Pembuatan Pati Ubi Jalar}

Pada penelitian ini terdapat beberapa prosedur yang dilakukan untuk memperoleh pati ubi jalar. Tahapan yang dilakukan dalam pembuatan pati ubi jalar adalah masing-masing $500 \mathrm{~g}$ ubi jalar dari varietas lokal, muara, jago, dan sukuh disortasi dari yang busuk dan rusak akibat gesekan maupun serangan hama. Kulit dibersihkan dari kotoran seperti tanah, pasir, dan lainnya dengan menggunakan air, kemudian kulit dikupas dengan menggunakan pisau dan umbi dicuci agar bersih dari lendir yang terdapat pada lapisan luar, lalu umbi direndam dalam air selama 1 jam dengan tujuan untuk melunakkan jaringan umbi agar umbi lebih mudah diparut. Selanjutnya umbi digiling menggunakan mesin penggiling dan hasilnya berupa bubur umbi. Bubur umbi yang diperoleh diekstraksi dengan air sebanyak 1 bagian bubur dengan 2 bagian air, diaduk-aduk agar pati lebih banyak terlepas dari sel umbi. Kemudian bubur umbi disaring dengan kain saring sehingga pati lolos dari saringan sebagai suspensi pati dan ampas tertinggal pada kain saring. Suspensi pati dibiarkan mengendap didalam wadah pengendapan selama 8 jam. Pati akan mengendap, selanjutnya dilakukan penirisan untuk memisahkan pati dengan cairan. Endapan pati dikeringkan menggunakan oven dengan suhu $40^{\circ} \mathrm{C}, 50^{\circ} \mathrm{C}$, dan $60^{\circ} \mathrm{C}$ selama 6 jam selanjutnya didinginkan. Setelah proses pengeringan selesai maka akan dihasilkan pati kasar dan dilakukan pengecilan ukuran menggunakan hammer mill, maka hasil dari penepungan diayak dengan ayakan berukuran 80 mesh sehingga dihasilkan pati ubi jalar halus.

\section{Analisis Sifat FisikoKimia Pati Ubi Jalar}

Parameter pengamatan yang dilakukan pada sifat fisikokimia pati ubi jalar ini meliputi rendemen, penentuan suhu gelatinisasi (Kartikasari et al., 2016), swelling power (Swinkels, 1987), kadar air (Apriyantono et al., 1989), kadar abu (Sudarmadji et al., 1996), kadar pati (Apriyantono et al., 1989), dan uji organoleptik terhadap warna (Soekarto, 1985).

\section{Analisis Data}

Semua data yang disajikan dalam penelitian ini dianalisis menggunakan analisis sidik ragam atau Analysis of Variance (ANOVA) dengan software SPSS 2010. Apabila hasil ANOVA menunjukkan adanya perbedaan pada perlakuan maka dilanjutkan dengan uji Beda Nyata Terkecil (BNT) dengan taraf 5\%.

\section{HASIL DAN PEMBAHASAN}

\section{Rendemen}

Rendemen merupakan nisbah antara hasil yang diperoleh dengan bahan dasarnya. Rendemen pati ubi jalar yang dihasilkan berkisar antara 9.87-1493\% dengan rendemen rata-rata $11.92 \%$. Hasil analisis sidik ragam menunjukkan bahwa faktor varietas ubi jalar berpengaruh sangat nyata terhadap rendemen pati ubi jalar yang dihasilkan. Suhu pengeringan dan interaksi keduanya memberikan pengaruh yang tidak nyata terhadap rendemen pati ubi jalar yang dihasilkan. Hasil uji Beda Nyata Terkecil (BNT 0.01) rendemen dengan pengaruh varietas ubi jalar dapat dilihat pada Gambar 1.

Gambar 1 menunjukkan bahwa rendemen pati ubi jalar tertinggi diperoleh dari varietas sukuh yaitu 13.97\%, sedangkan 
rendemen pati terendah diperoleh dari varietas muara yaitu $10.86 \%$. Menurut Suismono (2002), rendemen pati ubi-ubian umumnya rendah, seperti rendemen pati ubi kayu (tapioka), pati ganyong, dan pati ubi jalar masing-masing sebesar $25 \%$, $15.8 \%$, dan $15.2 \%$.

Menurut Rahman et al. (2015), pada proses produksi pati, ekstraksi merupakan faktor yang sangat berpengaruh terhadap kualitas rendemen pati yang dihasilkan. Rendemen pati sangat berhubungan dengan kadar pati yang terkandung dalam ubi kayu. Perbedaan rendemen pati yang dihasilkan diduga disebabkan dari perbedaan kadar pati bahan dasarnya. Adapun kadar pati segar masing-masing varietas ubi jalar yaitu lokal $65.07 \%$, muara $22.64 \%$, jago $24.47 \%$, dan sukuh 94.56\% (Ginting et al., 2005; Ginting et al., 2014; Ginting et al., 2018). Namun, kadar pati setelah ekstraksi pada penelitian untuk varietas sukuh $(78.11 \%)$ lebih tinggi daripada varietas muara $(66.12 \%)$ sehingga rendemen pati yang dihasilkan varietas sukuh lebih banyak daripada varietas muara.

Proses ekstraksi dan penirisan pati juga akan mengakibatkan susut bobot pati akan semakin berkurang sehingga akan mempengaruhi rendemen dari pati ubi jalar yaitu berkurangnya rendemen yang dihasilkan. Perbedaan rendemen yang dihasilkan juga telah terlihat pada proses penirisan endapan pati, dari keempat varietas yang digunakan, varietas muara, menghasilkan endapan pati yang lebih sedikit dan tekstur endapan lebih lembek dibandingkan varietas sukuh, jago, dan lokal yang endapannya lebih banyak dan padat. Rahayuningsih et al., (2012) menambahkan bahwa rendemen pati ubi jalar dipengaruhi oleh sifat genetik varietas, umur panen, dan juga lingkungan tumbuh.

\section{Suhu Gelatinisasi}

Berdasarkan penelitian diperoleh suhu gelatinisasi pati ubi jalar dari berbagai varietas dan suhu pengeringan berkisar antara 61$72{ }^{\circ} \mathrm{C}$ dengan nilai rata-rata suhu gelatinisasi $66.92{ }^{\circ} \mathrm{C}$. Hasil analisis sidik ragam suhu gelatinisasi menunjukkan bahwa varietas ubi jalar berpengaruh nyata terhadap suhu gelatinisasi pati ubi jalar, sedangkan suhu pengeringan dan interaksi keduanya berpengaruh tidak nyata terhadap suhu gelatinisasi pati. Gambar 2 memperlihatkan pengaruh varietas ubi jalar terhadap suhu gelatinisasi pati ubi jalar. Suhu gelatinisasi tiap-tiap pati berbeda dan merupakan suatu kisaran. Hal ini disebabkan karena populasi granula yang bervariasi dalam ukuran, bentuk, dan energi yang diperlukan untuk mengembang. Pada saat granula pati yang terdapat di dalam tepung mulai pecah, maka akan diperoleh suhu gelatinisasi pati. Semakin rendah suhu gelatinisasi, waktu gelatinisasi juga semakin pendek (Dewi et al., 2012).

Gambar 2 menunjukkan bahwa suhu gelatinisasi terendah diperoleh dari varietas muara, sedangkan suhu gelatinisasi tertinggi diperoleh dari varietas sukuh. Kisaran suhu gelatinisasi tersebut sesuai dengan kisaran yang dikemukakan Moorthy (2004), yaitu sekitar $66-86.3^{\circ} \mathrm{C}$. Suhu gelatinisasi memiliki hubungan dengan kadar amilosa pati, dimana semakin tinggi kadar amilosa pati, maka pada umumnya suhu gelatinisasi semakin tinggi (Fennema, 2008). Tingginya suhu gelatinisasi mengindikasikan adanya keberadaan pati yang resisten untuk mengembang (Maninder et al., 2006).

\section{Swelling Power}

Sifat dasar granula pati adalah kemampuannya membengkak (swelling) dan menghasilkan pasta. Bila suspensi pati dari granula pati dipanaskan diatas suhu gelatinisasi, maka granula pati akan sangat menyerap air dan mengembang beberapa kali lipat. Peristiwa ini bersifat dapat balik (irreversible) (Antarlina, 1999).

Swelling power pati ubi jalar yang diperoleh pada penelitian ini berkisar antara $35.20-45.50 \%$ dengan rata-rata $40.78 \%$. Hasil analisis sidik ragam menunjukkan bahwa varietas ubi jalar dan suhu pengeringan berpengaruh sangat nyata terhadap nilai swelling power pati ubi jalar, sedangkan interaksi antara keduanya memberikan pengaruh yang tidak nyata terhadap nilai swelling power pati ubi jalar. Gambar 3 memperlihatkan pengaruh varietas ubi jalar terhadap nilai swelling power.

Gambar 3 memperlihatkan bahwa nilai swelling powertertinggi diperoleh dari varietas sukuh yaitu $43.33 \%$ dan swelling power terendah diperoleh dari varietas lokal yaitu $38.23 \%$. Tingginya nilai swelling power varietas sukuh diduga karena sukuh memiliki kandungan amilopektin yang lebih tinggi daripada varietas lainnya. Semakin tinggi kandungan amilopektin maka akan semakin banyak menyerap air. Haryadi (1993) menyatakan bahwa amilopektin pada umumnya merupakan penyusun struktur utama granula kebanyakan pati. 
Jurnal Teknologi Pertanian Vol. 20 No. 1 [April 2019] 33-44

Karakteristik Sifat Fisikokimia Pati Ubi Jalar [Irhami dkk]

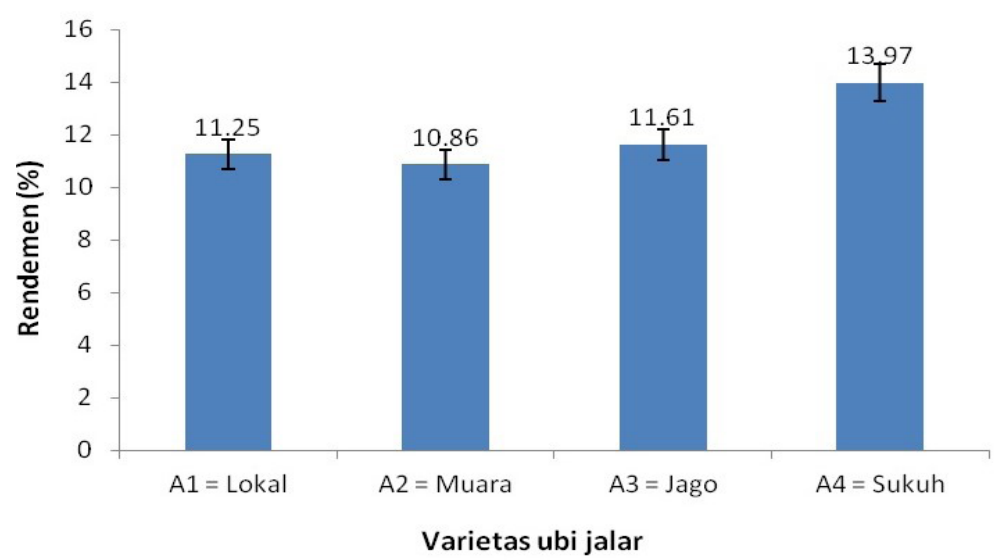

Gambar 1. Pengaruh varietas ubi jalar terhadap rendemen pati ubi jalar (BNT $0.05=1.34, \mathrm{KK}=8.6 \%$

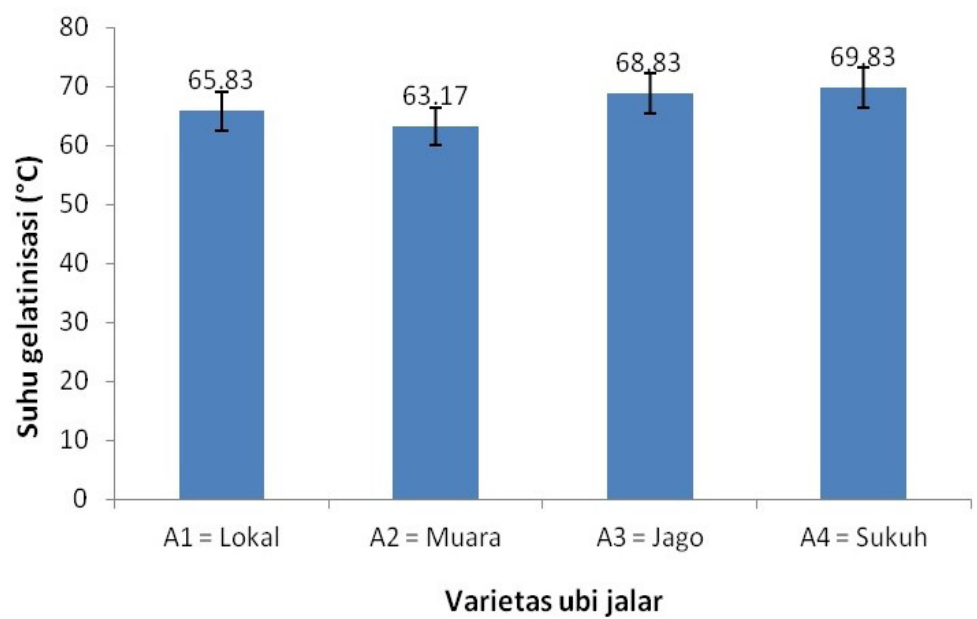

Gambar 2. Pengaruh varietas ubi jalar terhadap suhu gelatinisasi pati ubi jalar (BNT $0.05=1.82$, $\mathrm{KK}=2.15 \%)$

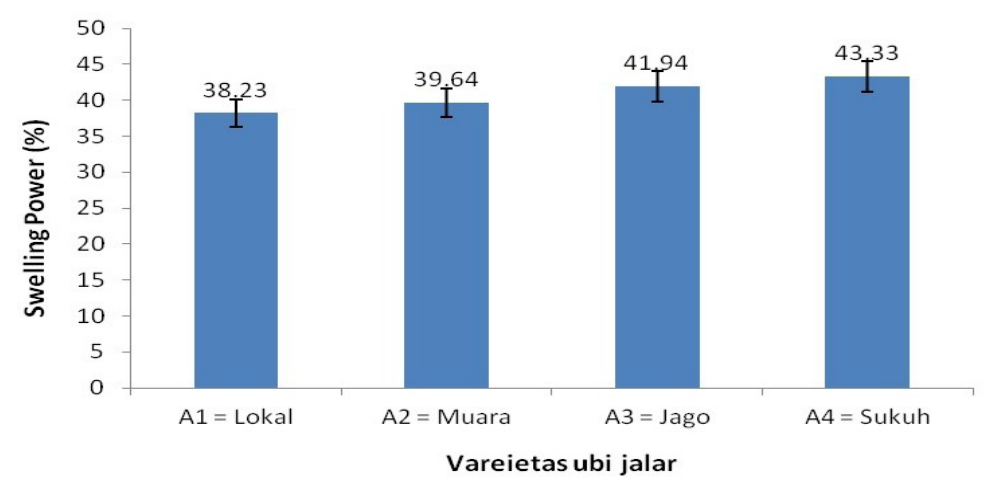

Gambar 3. Pengaruh varietas ubi jalar terhadap swelling power pati ubi jalar (BNT $0.05=061$, KK $=1,19 \%)$ 
Jurnal Teknologi Pertanian Vol. 20 No. 1 [April 2019] 33-44

Karakteristik Sifat Fisikokimia Pati Ubi Jalar [Irhami dkk]

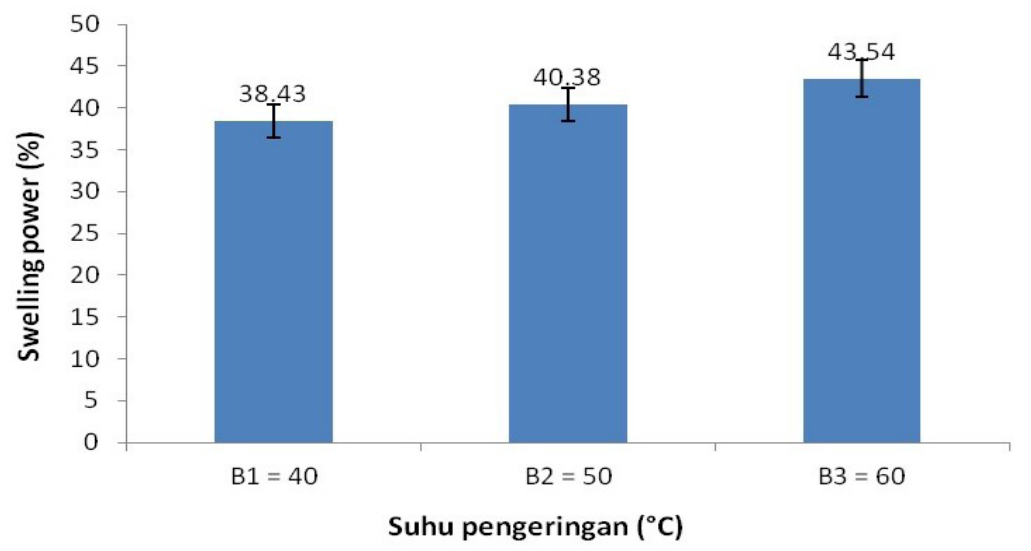

Gambar 4. Pengaruh suhu pengeringan terhadap swelling power pati ubi jalar (BNT $0.05=0.53, \mathrm{KK}=1.19 \%$ )

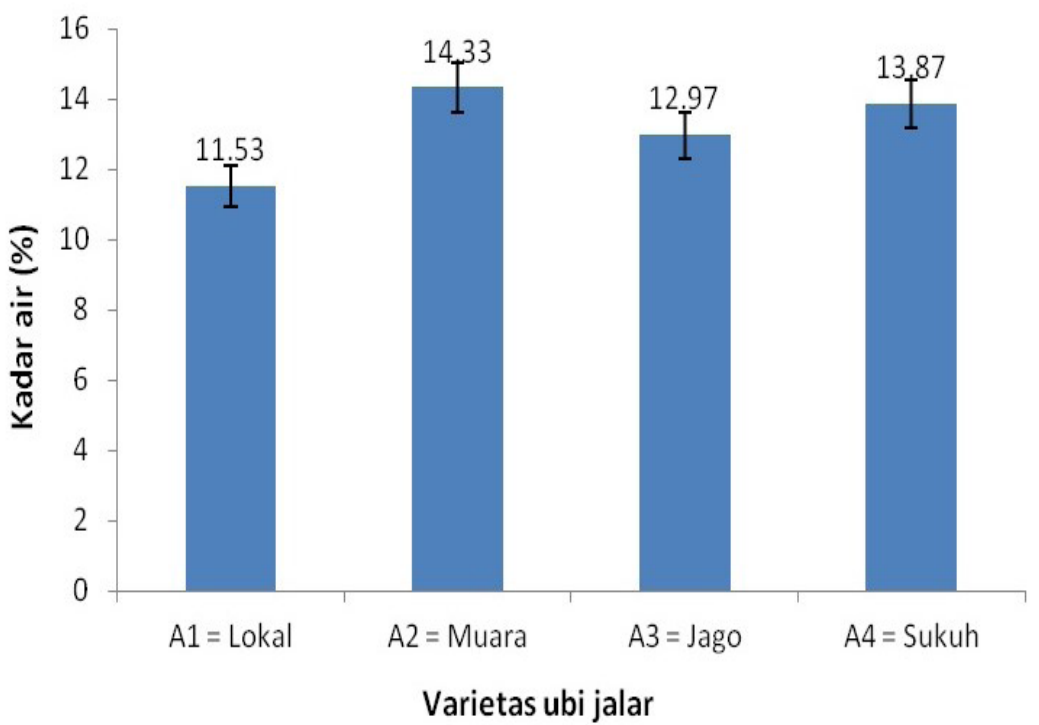

Gambar 5. Pengaruh varietas ubi terhadap kadar air pati ubi jalar (BNT $0.05=1.08, \mathrm{KK}=6.55 \%$ )

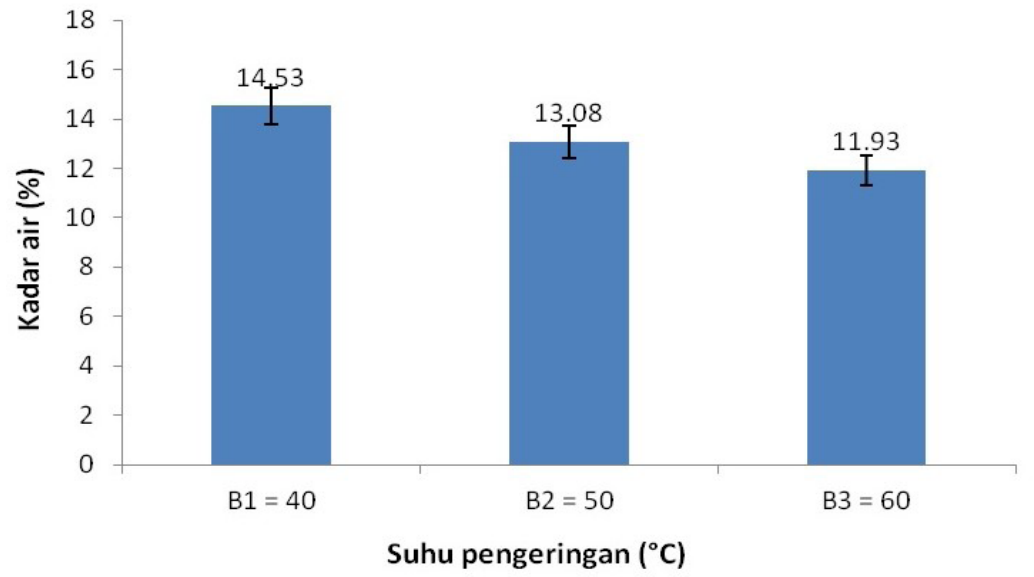

Gambar 6. Pengaruh suhu pengeringan terhadap kadar air pati ubi jalar $(\mathrm{BNT} 0.05=0.94, \mathrm{KK}=6.55 \%)$ 
Jurnal Teknologi Pertanian Vol. 20 No. 1 [April 2019] 33-44

Karakteristik Sifat Fisikokimia Pati Ubi Jalar [Irhami dkk]

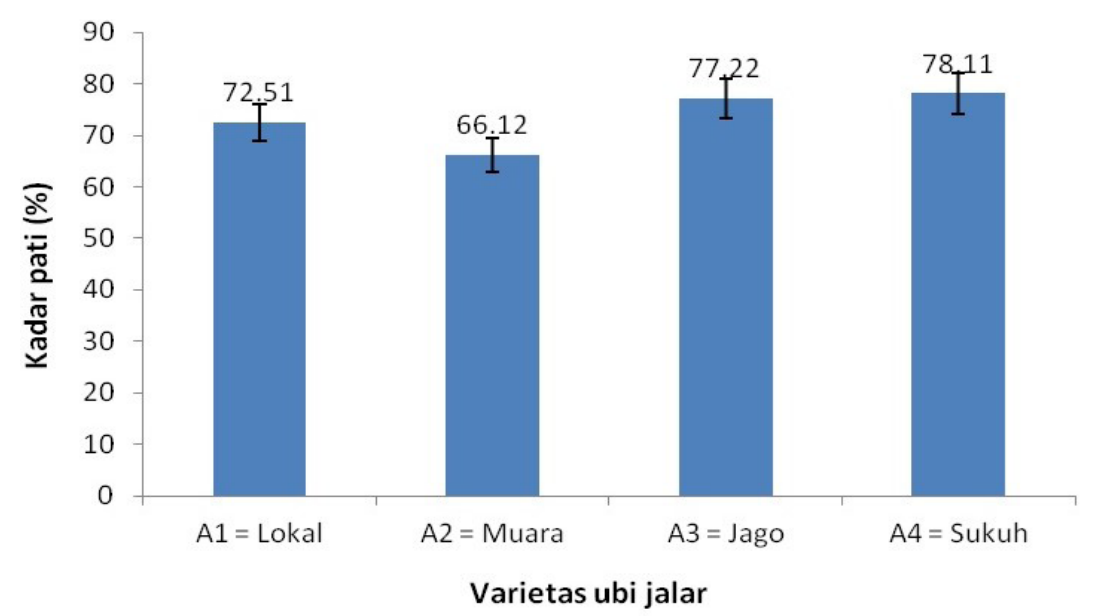

Gambar 7. Pengaruh varietas ubi jalar terhadap kadar pati ubi jalar (BNT $0.05=8.16, \mathrm{KK}=8.83 \%$ )

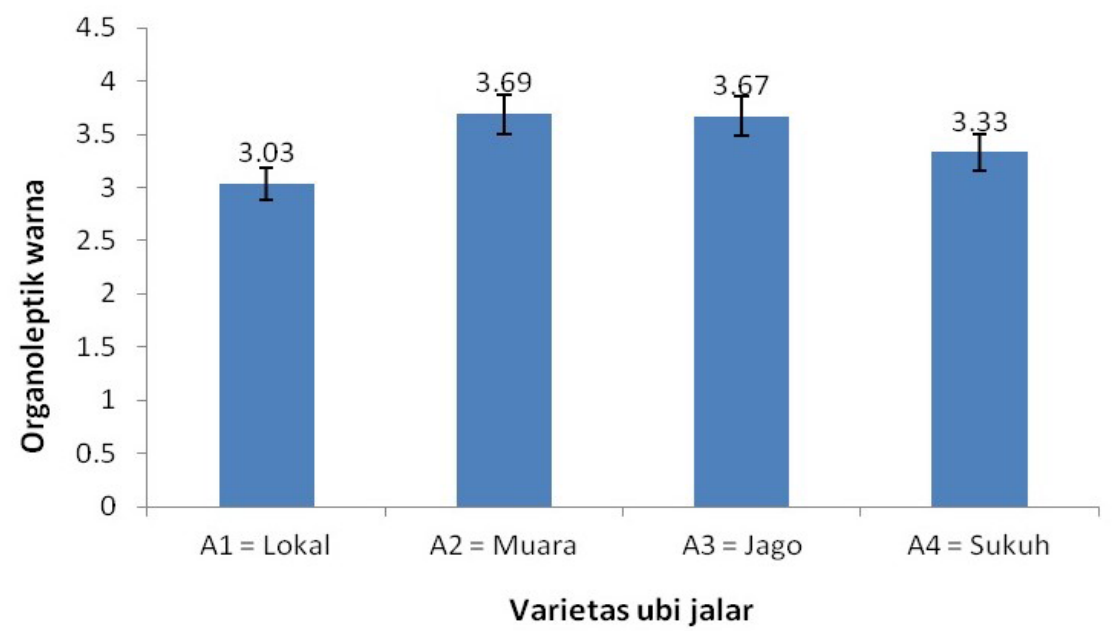

Gambar 8. Pengaruh varietas ubi jalar terhadap warna pati ubi jalar (BNT $0.05=0.30, \mathrm{KK}=7.19 \%$ )

Tabel 1.

\begin{tabular}{lccc}
\hline \multirow{2}{*}{ Varietas ubi jalar } & \multicolumn{3}{c}{ Suhu Pengeringan } \\
\cline { 2 - 4 } & $\mathbf{4 0}{ }^{\circ} \mathbf{C}$ & $50^{\circ} \mathbf{C}$ & $60^{\circ} \mathbf{C}$ \\
\hline lokal & $4.76 \mathrm{a}$ & $6.87 \mathrm{~b}$ & $5.32 \mathrm{~b}$ \\
muara & $5.25 \mathrm{~b}$ & $5.28 \mathrm{~b}$ & $5.76 \mathrm{~b}$ \\
jago & $3.09 \mathrm{a}$ & $6.92 \mathrm{ab}$ & $7.31 \mathrm{ab}$ \\
sukuh & $5.00 \mathrm{~b}$ & $6.07 \mathrm{ab}$ & $5.16 \mathrm{~b}$ \\
\hline
\end{tabular}


Bagian ini merupakan susunan yang kurang kompak atau amorf sehingga lebih mudah dicapai oleh air.

Santosa et al. (1997) juga telah meneliti daya mengembang (swelling power) pati yang diperoleh dari dua varietas ubi jalar yaitu varietas bentul yang berdaging umbi merah dan varietas ciceh yang berdaging umbi putih. Hasil penelitian tersebut menunjukkan bahwa varietas ciceh daya mengembangnya lebih tinggi yaitu sekitar $21.59 \%$ dibandingkan varietas bentul sekitar $19.50 \%$. Hal ini disebabkan karena kadar amilopektin varietas bentul lebih rendah dibandingkan varietas ciceh.

Gambar 4 memperlihatkan bahwa nilai swelling pati ubi jalar tertinggi diperoleh pada pengeringan dengan suhu $60^{\circ} \mathrm{C}$ sedangkan nilai swelling power terendah diperoleh pada pengeringan dengan menggunakan suhu 40 ${ }^{\circ} \mathrm{C}$. Tingginya nilai swelling power pada pengeringan $60{ }^{\circ} \mathrm{C}$ kemungkinan disebabkan pada saat pati basah dikeringkan dengan suhu $60{ }^{\circ} \mathrm{C}$ terdapat sebagian granula yang telah mengalami gelatinisasi. Biasanya pati yang telah tergelatinisasi memiliki kemampuan menyerap air yang lebih besar. Winarno (1995) menyatakan bahwa pati yang telah mengalami gelatinisasi dapat dikeringkan, tetapi molekul-molekulnya tidak dapat kembali lagi ke sifat asal. Pati yang telah kering tersebut masih mampu menyerap air bahkan dalam jumlah yang lebih besar dibandingkan dengan pati yang belum tergelatinisasi. Semakin tinggi suhu yang digunakan maka nilai swelling power akan semakin tinggi.

\section{Kadar Air}

Kadar air merupakan banyaknya air yang terkandung dalam suatu bahan yang dinyatakan dalam persen (\%). Kadar air yang tinggi mengakibatkan mudahnya bakteri, kapang, dan khamir untuk berkembang biak sehingga akan menyebabkan terjadinya perubahan pada bahan.

Kadar air pati ubi jalar dari berbagai varietas dan suhu pengeringan berkisar antara $8.2-16.40 \%$ dengan nilai rata-rata keseluruhan $13.18 \%$. Hasil analisis sidik ragam kadar air pati ubi jalar menunjukkan bahwa varietas ubi jalar dan suhu pengeringan berpengaruh sangat nyata, sedangkan interaksi keduanya memberikan pengaruh yang tidak nyata terhadap kadar air pati ubi jalar. Gambar 5 memperlihatkan pengaruh varietas ubi jalar terhadap kadar air pati ubi jalar.
Gambar 5 dapat dilihat bahwa kadar air tertingi terdapat pada varietas muara yaitu sebesar $14.33 \%$, sedangkan kadar air terendah diperoleh dari varietas lokal yaitu $11.53 \%$. Tingginya kadar air pada varietas muara diduga karena pada varietas muara yang berdaging umbi merah memiliki kandungan air bahan yang lebih tinggi dibandingkan dengan varietas lokal yang memiliki warna daging umbi kuning serta varietas jago dan sukuh yang berdaging umbi putih. Adanya perbedaan kandungan air air awal pada bahan, sehingga berpengaruh terhadap kadar air pati yang dihasilkan. Adapun kadar air awal masing-masing varietas ubi jalar yaitu lokal $59.23 \%$, muara $70.47 \%$, jago $68.78 \%$, dan sukuh $68.80 \%$ (Ginting et al., 2005; Ginting et al., 2014; Ginting et al., 2018).

Suismono (1995) mengatakan bahwa kandungan air ubi jalar segar yang tertinggi dimiliki oleh ubi jalar dengan warna daging umbi merah yaitu sebesar $79.59 \%$, ubi jalar dengan daging umbi putih sekitar $67.60 \%$ dan kandungan air terendah dimiliki oleh umbi yang berwarna kuning yaitu $64.15 \%$.

Gambar 6 memperlihatkan bahwa kadar air tertinggi diperoleh dari pengeringan dengan menggunakan suhu $40{ }^{\circ} \mathrm{C}$. Hal ini disebabkan karena semakin tinggi suhu pengeringan yang digunakan maka kadar air pati ubi jalar yang dihasilkan juga semakin rendah. Semakin tinggi suhu pengeringan akan semakin besar energi panas yang dibawa oleh udara sehingga semakin banyak jumlah massa cairan yang diuapkan dari permukaan bahan yang dikeringkan.

Menurut Vallous (2002), peningkatan tekanan uap atau suhu pengeringan menyebabkan terjadinya penurunan kadar air bahan. Penurunan kadar air bahan akan sampai pada tititk kesetimbangan, dimana migrasi air dari permukaan bahan menuju udara kering mengakibatkan konsentrasi air dalam bahan pangan semakin lama, akan semakin berkurang, dan mengakibatkan turunnya tekanan uap. Perbedaan tekanan uap semakin menurun maka penguapan air dalam permukaan bahan akan berkurang. Hal ini mengakibatkan kecepatan perpindahan air dari bagian dalam bahan menuju permukaan juga akan berkurang.

\section{Kadar Abu}

Kadar abu bahan dapat diketahui dengan mengoksidasikan semua zat organik pada suhu tinggi dan kemudian melaku- 
kan penimbangan zat yang tertinggal setelah proses pembakaran tersebut. Kandungan abu dan kompisisinya tergantung dari macam bahan (Sudarmadji et al., 1994).

Berdasarkan hasil analisis kadar abu menunjukkan bahwa kadar abu pati ubi jalar yang dihasilkan berkisar antara 2.2-7.93\% dengan rata-rata keseluruhan 5.56\%. Hasil analisis sidik ragam terlihat bahwa varietas ubi jalar, suhu pengeringan dan interaksi keduanya berpengaruh tidak nyata terhadap kadar abu pati ubi jalar.

Tabel 1. menunjukkan bahwa nilai rata-rata kadar abu yang dihasilkan dari perlakuan antar varieatas ubi jalar dan suhu pengeringan hampir sama dan nilai kadar abu tersebut dapat dikatakan cukup tinggi, walaupun analisis sidik ragam tidak menunjukkan pengaruh nyata.

Menurut Sriwahyuni et al., (2017), kandungan abu yang dimiliki tepung ubi jalar adalah maksimal sebesar $2.58 \%$. Namun pada penelitian, ini kadar abu yang diperoleh lebih tinggi dari yang penelitian yang dilakukan oleh Sriwahyuni et al., (2017) yaitu 7.31\% sehingga dapat dikatakan bahwa kadar abu yang dihasilkan masih terlalu tinggi dari persyaratan yang telah ditetapkan.

Tingginya kadar abu dapat disebabkan pada saat proses penggilingan, kandungan mineral menjadi bertambah karena terjadinya gesekan dengan mesin penggiling. Kadar abu juga dapat menunjukkan kandungan bahan selain bahan organik. Kandungan abu mempengaruhi mutu pati ubi jalar yang dihasilkan yaitu warna dan kandungan mineralnya. Kandungan abu yang terlalu tinggi dapat menyebabkan warna yang kurang baik pada pati.

\section{Kadar Pati}

Kandungan pati ubi jalar yang diperoleh pada penelitian ini berkisar antara 59.2$80.76 \%$ dengan nilai rata-rata kadar pati secara keseluruhan adalah 73.49\%. Hasil analisis sidik ragam menunjukkan bahwa varietas ubi jalar berpengaruh nyata terhadap kadar pati ubi jalar, sedangkan suhu pengeringan dan interaksi antara keduanya berpengaruh tidak nyata terhadap kadar pati yang dihasilkan. Gambar 7 memperlihatkan pengaruh varietas ubi jalar terhadap kadar pati ubi jalar.

Gambar 7 dapat dilihat bahwa varietas ubi jalar yang memiliki kadar pati tertinggi diperoleh dari varietas sukuh $(78.11 \%)$ dan kadar pati terendah diperoleh dari varietas muara (66.12\%). Adanya perbedaan kadar pati tersebut diduga karena setiap varietas memiliki kandungan pati yang tidak sama. Warna daging umbi yang beragam ternyata juga mempengaruhi kadar pati yang dihasilkan. Varietas sukuh yang berwarna daging umbi putih lebih tinggi kandungan patinya dibandingkan varietas muara yang berdaging umbi merah. Lingga (1986) menyatakan bahwa kandungan pati ubi jalar segar berbeda tergantung dari warna daging umbi. Ubi jalar dengan warna daging umbi putih memiliki kandungan pati $28.19 \%$, ubi jalar dengan warna daging umbi kuning sekitar $25.34 \%$, dan ubi jalar dengan warna daging umbi merah kandungan patinya sekitar $17.06 \%$.

Menurut Jane et al., (1999), kadar amilosa dan amilopektin sangat berperan pada saat proses gelatinisasi, retrogradasi dan lebih menentukan karakteristik pasta pati. Imanningsih (2012) menambahkan bahwa gelatinisasi dan sifat pembengkakan dari setiap jenis pati sebagian dikontrol oleh struktur amilopektin, komposisi pati dan arsitektur granula. Ketika pati dipanaskan bersama air berlebih diatas suhu gelatinisasinya, granula pati yang memiliki kandungan amilopektin lebih tinggi akan membengkak lebih besar dibandingkan dengan yang memiliki kandungan yang lebih rendah.

Namun pati yang berkadar amilosa tinggi mempunyai kekuatan ikatan hidrogen yang lebih besar karena jumlah rantai lurus yang besar dalam granula, sehingga membutuhkan energi yang lebih besar untuk gelatinisasi (Richana dan Sunarti, 2004).

\section{Uji Organoleptik Warna}

Pengujian organoleptik merupakan salah satu pengukuran secara langsung pada suatu produk sebagai data kualitatif menggunakan manusia sebagai alat ukur. Pengujian organoleptik yang digunakan pada penelitian ini adalah uji hedonik yang disebut juga dengan uji kesukaan. Pada uji hedonik, panelis dimintakan tanggapan pribadi tentang kesukaan atau ketidaksukaan. Penentuan mutu bahan makanan pada umumnya sangat tergantung pada beberapa faktor diantaranya citarasa, warna, dan nilai gizinya. Tetapi faktor warna tampil lebih dahulu dan kadang-kadang sangat menentukan (Winarno, 1995).

Pengujian organoleptik yang dilakukan pada pati ubi jalar menunjukkan bahwa 
rata-rata kesukaan panelis terhadap warna pati ubi jalar yang dihasilkan berkisar antara 2.60-4.35 (penerimaan antara biasa sampai suka) dengan rata-rata keseluruhan 3.43. Hasil analisis sidik ragam memperlihatkan bahwa varietas ubi jalar berpengaruh sangat nyata terhadap tingkat penerimaan panelis pada warna pati ubi jalar. Sedangkan faktor suhu pengeringan dan interaksi antara keduanya memberikan yang tidak nyata.

Gambar 8 menunjukkan bahwa panelis menyukai warna pati ubi jalar dari varietas muara dengan nilai organoleptik warna 3.69 (penerimaan antara biasa sampai suka). Hal ini diduga karena varietas muara yang berdaging umbi merah mengandung karoten yang lebih tinggi dibandingkan varietas jago, lokal, dan sukuh sehingga mempengaruhi warna dari produk pati yang dihasilkan.

Karoten merupakan prekursor vitamin A yang tidak larut dalam air tetapi larut dalam lemak dan pelarut lemak (Andarwulan dan Koswara, 1992). Kadar karoten pada pati ubi jalar dapat diperkirakan dari warnanya, kecuali ubi jalar ungu. Semakin kuat intensitas warna kuningnya semakin besar kandungan karotennya. Kandungan karoten ubi jalar paling tinggi diantara padi-padian dan umbi-umbian lainnya (Sukirwan, 2000). Kadarisman (1985) juga menambahkan bahwa adanya senyawa-senyawa polipenol, asam askorbat, dan karoten menyulitkan memperoleh tepung pati berwarna putih yang diinginkan.

Semua jenis ubi jalar dapat dibuat menjadi pati tetapi kualitas pati yang dihasilkan berbeda. Warna pati yang dihasilkan sangat dipengaruhi oleh jenis dan warna umbi ubi jalar yang digunakan (Sanifsoetan, 1987). Warna umbi jalar yang berbeda-beda mempengaruhi warna dari pati yang dihasilkan tetapi hal ini tidak membatasi penggunaan pati ubi jalar sebagai bahan baku industri karena dapat digunakan sesuai kebutuhan, misalnya pati ubi jalar yang berwarna ungu dapat digunakan untuk produk yang berwarna coklat sedangkan untuk kue kering dapat digunakan pati yang berasal dari umbi yang dagingnya kuning atau putih (Antarlina, 1999).

\section{SIMPULAN}

Berdasarkan pengaruh varietas ubi jalar, rendemen, suhu gelatinisasi, swelling power, dan kadar pati tertinggi diperoleh dari varietas sukuh dan diikuti oleh varietas jago, lokal, dan muara, sedangkan kadar air tertinggi diperoleh dari pati ubi jalar varietas muara dan kadar air terendah dari varietas lokal. Berdasarkan perlakuan suhu pengeringan, swelling power, dan kadar air tertinggi diperoleh dari perlakuan suhu $60^{\circ} \mathrm{C}$, sedangkan swelling power dan kadar air terendah diperoleh dari perlakuan suhu $40{ }^{\circ} \mathrm{C}$. Berdasarkan uji organoleptik, pati ubi jalar yang disukai panelis adalah pati ubi jalar varietas muara dengan nilai kesukaan 3.69 (penerimaan antara biasa sampai suka).

\section{DAFTAR PUSTAKA}

Andarwulan, N, Koswara, S. 1992. Kimia Vitamin. Rajawali, Jakarta

Antarlina, SS. 1999. Pengaruh Umur Panen dan Klon Terhadap Beberapa Sifat Fisik dan Kimiawi Tepung Ubi Jalar. Tesis. Universitas Brawijaya. Malang

Afriani, L, H. 2004. Pati termodifikasi dibutuhkan industri makanan. Dilihat 2 Januari 2006. <http://www.pikiranrakyat.com/cakrawala/penelitian htm>

Alim, E. 2004. Mutu Cita Rasa Rengginang Berbasis Beras Aromatik dengan Metode Pengeringan Berbeda. Skripsi. IPB. Bogor

Apriyantono, AD, Fardiaz, 1, Puspitasari, Sedarnawati, Budiyanto, S. 1989. Petunjuk Laboratorium : Analisis Pangan. IPB, Bogor

Dewi, N, -S., Utami, -R., Riyadi, N, -H., 2012. Aktivitas antioksidan dan antimikroba ekstrak melinjo (Gnetum gemon L). Jurnal Teknologi Hasil Pertanian. 5, 104-112. http://dx.doi.org/10.20961/jthp.v0i0

Fennema, OR. 2008. Food Chemistry. CRC Press, New York

Ginting, -E., Widodo, -Y., Rahayuningsih, S, -A., Jusuf, -M., 2005. Karakteristik pati beberapa varietas ubi jalar. Jurnal Tanaman Pangan. 24, 8-18. http://pangan.litbang.pertanian.go.id/tanaman- 
pangan-307.html

Ginting, -E., Yulifianti, -R., Jusuf, -M., 2014. Ubi jalar sebagai bahan diversifikasi pangan lokal. Jurnal Pangan. 23, 194207. http://jurnalpangan.com/index. php/pangan/article/view/63/57

Ginting, -E., Yulifianti, -R., Elisabeth, D, A, -A., 2018. Karakteristik fisik, kimia, dan sensori ubi jalar pada berbagai pemupukan di lahan pasang surut kalimantan selatan. Buletin Palawija. 16, 36-45. http://dx.doi.org/10.21082/ bulpa.v16n1.2018.p36-45

Haryadi. 1993. Dasar-dasar dan pemanfaatan ilmu dan teknologi pati. Agritech. 13, 37-42

Histifarina, -D, Sinaga, R, -M., 1999. Pengaruh suhu dan lama pengeringan terhadap mutu tepung wortel. Buletin Pasca Panen Hortikultura. 1, 25-30

Immanningsih, -N., 2012. Profil gelatinisasi beberapa formulasi tepung tepungan untuk pendugaan sifat pemasakan. Penelitian Gizi Makan. 35, 13-22

Jane, -J., Chen, Y, -Y., Lee, L, -F., McPherson, A, -E., Wong, K, -S., Radosavljevics, -M., Kasemsuwan, -K., 1999. Effect of amylopectin brain chain length and amylose content on the gelatinization and pasting properties of starch. Cereal Chemistry. 76(5): 629 - 637. https:/ / doi. org/10.1094/CCHEM.1999.76.5.629

Jusuf, -M., Antarlina, S, -S, Supriantin, Irfansyah, Suripan. 1998. Daya dukung klon-klon atau varietas ubi jalar untuk produk-produk pangan. Lokakarya Nasional Pemberdayaan Tepung Ubi Jalar Sebagai Bahan Substitusi Terigu, Balai Penelitian Tanaman Aneka Kacang dan Umbi, Malang

Kadarisman. 1985. Pengaruh Penambahan Kapur, Jumlah Air Ekstraksi dan Lama Pengendapan Terhadap Rendemen dan Mutu Pati Ubi Jalar. Tesis. IPB. Bogor

Kartikasari, S, -N., Sari, -P., Subagio, -A., 2016. Karakterisasi sifat kimia, profil amilografi (RVA) dan morfologi granula (SEM) pati singkong termodifikasi secara biologi. Jurnal Agroteknologi. 10, 12-24. https://jurnal.unej.ac.id/index. php/JAGT/article/view/4472/3327

Lingga, P. 1986. Bertanam Ubi-Ubian. Penebar Swadaya, Jakarta

Maninder, -K., Sandhu, K, -S., Singh, -N., 2006. Comparative study of the fuc- tional, thermal, and pasting properties of flours from different field pea (Pisum sativum L.) and pigeon pea (Cajanus cajan L.) cultivars. Food Chemistry. 104, 259-267. https://doi.org/10.1016/j. foodchem.2006.11.037

Martunis. 2012. Pengaruh suhu dan lama pengeringan terhadap kuantitas dan kualitas pati kentang varietas granola. Jurnal Teknologi dan Industri Pertanian Indonesia. 3(4):26-30. https://doi. org/10.17969/jtipi.v4i3.740

Muchtadi, TR. 1989. Teknologi Proses Pengolahan Pangan. IPB, Bogor

Moorthy, SN. 2004. 'Tropical sources of starch'. Dalam AC Eliasson (ed). Starch In Foods, Structure, function and applications. CRC Press, New York

Novary, EW. 1997. Penanganan dan Pengolahan Sayuran Segar. Penebar Swadaya, Jakarta

Rahayuningsih, S, A, Jusuf, M, Wahyuni, T, S. 2012. Perkembangan umbi dan pembentukan pati klon-klon harapan ubi jalar kaya $\beta$-karotin dan antosianin pada berbagai umur panen. Prosiding Seminar Hasil Penelitian Tanaman Anekan Kacang dan Umbi, Balai Penelitian Tanaman Aneka Kacang dan Umbi, Malang, pp. 580-589

Rahman, -N., Fitriani, -H., Hartati, S, -N., 2015. Seleksi ubi kayu berdasarkan perbedaan waktu panen dan inisiasi kultur in vitro. Prosiding Seminar Nasional Masyarakat Biodiversitas Indonesia. 1, 1761-1765. https://doi. org/10.13057/psnmbi/m010803

Richana, -N., Sunarti, T, -C., 2004. Karakterisasi sifat fisikokimia tepung umbi dan tepung pati dari umbi ganyong, suweg, ubi kelapa dan gembili. Jurnal Pascapanen. 1, 29-37. http://pascapanen.litbang.pertanian.go.id/assets / media/publikasi/jurnal/j.Pascapanen.2004_1_4.pdf

Santosa, B, A, S, Narta, Widowati, S. 1997. Studi karakteristik pati ubi jalar. Prosiding Seminar Teknologi Pangan, Denapasar, Bali, pp. 301-307

Sriwahyuni, M, -N., Wijaya, -M., Kadirman. 2017. Pemanfaatan tepung ubi jalar (Ipomea btatas L) berbagai varietas sebagai bahan baku pembuatan kue bolu kukus. Jurnal Pendidikan Teknologi Pertanian. 3, 60-71. https://doi. org/10.26858/jptp.v3i0.5465 
Jurnal Teknologi Pertanian Vol. 20 No. 1 [April 2019] 33-44

Karakteristik Sifat Fisikokimia Pati Ubi Jalar [Irhami dkk]

Suismono. 2002. Kajian teknologi pembuatan tepung dan pati umbi-umbian untuk menunjang ketahanan pangan. Majalah pangan media komunikasi dan informasi. 37, 37-49

Sukirwan, Q, N. 2000. Ubi jalar kurangi resiko buta. Dilihat 2 Januari 2006. http:// kompas.com/kompascetak/0010/22/ Iptek.Ubi21.htm./

Sanifsoetan. 1987. Ubi Jalar. Balai Pustaka, Jakarta

Soekarto, T. 1985. Penilaian Organoleptik Untuk Industri Pangan dan Hasil Pertanian. Bharatara Karya Aksara, Jakarta

Swinkles, J, J, M. 1987. 'Source of Starch, Its Chemistry and Physics'. Dalam Van
Beynum GMA dan Roels JA. Starch Convertion Technology. Marcel Dekker, New York

Sudarmadji, S, B, Haryono, Suhardi. 1994. Prosedur Analisa untuk Bahan Makanan dan Pertanian. PAU UGM, Yogyakarta

Valous, -N., Gavrielidou, M, -A., Karapantsio, T, -D., Kostoglou, -M., 2002. Performance of a double drum dryer for producing pregelatinized maize starches. Journal of Food Engineering. 51, 171-183. https://doi.org/10.1016/ S0260-8774(01)00041-3

Winarno, FG. 1995. Kimia Pangan dan Gizi. Gramedia Pustaka Utama, Jakarta 